\title{
Where do hands go? An audit of sequential hand-touch events on a hospital ward
}

\author{
S.J. Smith ${ }^{\text {a }}$, V. Young ${ }^{\text {a }}$, C. Robertson ${ }^{\text {b, c }}$, S.J. Dancer ${ }^{\text {d, * }}$ \\ ${ }^{a}$ Department of Surgery, Hairmyres Hospital, Lanarkshire, UK \\ ${ }^{\mathrm{b}}$ Department of Mathematics and Statistics, University of Strathclyde, Glasgow, UK \\ ${ }^{c}$ International Prevention Research Institute, Lyon, France \\ ${ }^{\mathrm{d}}$ Department of Microbiology, Hairmyres Hospital, Lanarkshire, UK
}

\section{A R T I C L E I N F O}

\section{Article history:}

Received 23 August 2011

Accepted 14 December 2011

by J.A. Child

Available online $x x x$

\section{Keywords:}

Audit

Cleaning

Clinical equipment

Hand hygiene

Healthcare environment

Surveillance

\begin{abstract}
$S U M M A R Y$
Background: Reservoirs of pathogens could establish themselves at forgotten sites on a ward, posing a continued risk for transmission to patients via unwashed hands.

Aim: To track potential spread of organisms between surfaces and patients, and to gain a greater understanding into transmission pathways of pathogens during patient care.

Methods: Hand-touch activities were audited covertly for $40 \times 30$ min sessions during summer and winter, and included hand hygiene on entry; contact with near-patient sites; patient contact; contact with clinical equipment; hand hygiene on exit; and contact with sites outside the room.

Findings: There were 104 entries overall: 77 clinical staff (59 nurses; 18 doctors), 21 domestic staff, one pharmacist and five relatives. Hand-hygiene compliance among clinical staff before and after entry was 25\% (38/154), with higher compliance during 20 summer periods [47\%; 95\% confidence interval $(\mathrm{Cl})$ : 35.6-58.8] than during 20 winter periods $(7 \% ; 95 \% \mathrm{Cl}: 3.2-14.4 ; P<0.0001)$. More than half of the staff $(58 \% ; 45 / 77)$ touched the patient. Staff were more likely to clean their hands prior to contact with a patient [odds ratio (OR): $3.44 ; 95 \% \mathrm{Cl}: 0.94-16.0) ; P=0.059$ ] and sites beside the patient (OR: 6.76; 95\% Cl: 1.40-65.77; $P=0.0067)$. Nearly half $(48 \% ; 37 / 77)$ handled patient notes and $25 \%$ touched the bed. Most frequently handled equipment inside the room were intravenous drip (30\%) and blood pressure stand (13\%), and computer (26\%), notes trolley $(23 \%)$ and telephone $(21 \%)$ outside the room.

Conclusion: Hand-hygiene compliance remains poor during covert observation; understanding the most frequent interactions between hands and surfaces could target sites for cleaning.
\end{abstract}

(C) 2011 The Healthcare Infection Society. Published by Elsevier Ltd. All rights reserved.
* Corresponding author. Address: Department of Microbiology, Hairmyres Hospital, East Kilbride G75 8RG, UK. Tel.: +44 (0) 1355 585000; fax: +44 (0) 1355584350.

E-mail address: stephanie.dancer@lanarkshire.scot.nhs.uk (S.J. Dancer).

\section{Introduction}

Hospital-acquired infections remain a problem for all hospitals. It is assumed that most infections arise from contaminated staff hands, which has led to the current focus on hand-hygiene initiatives. ${ }^{1}$ Whereas there has been some success in persuading staff to clean their hands, compliance rates frequently decrease when an intervention ceases. ${ }^{2}$ In

0195-6701/\$ - see front matter (c) 2011 The Healthcare Infection Society. Published by Elsevier Ltd. All rights reserved. doi:10.1016/j.jhin.2011.12.007 
addition, staff often forget hand hygiene when they are busy. Recent work has highlighted the role of the clinical environment in the transmission of ward-based infection. ${ }^{3}$ Any hand-touch site that escapes cleaning offers a potential reservoir for hospital microbes. Even good hand hygiene is rendered obsolete if staff then touch these sites after cleaning their hands. ${ }^{4}$

Hand-touch surfaces nearest the patient pose the highest infection risk. ${ }^{3,5,6}$ Sites that are regularly handled include call buttons, television controls, patient notes, equipment, furniture, computers, and telephones. All items and surfaces should be cleaned regularly by designated staff in accordance with written specifications but it is possible that some do not receive sufficient cleaning attention. ${ }^{7,8}$ This may be due to the widening gap between nursing and domestic duties and/or increasing provision of sophisticated equipment needing specialist cleaning. ${ }^{7,9}$ Compliance with cleaning is undoubtedly exacerbated by workload or confusion over who should clean what. ${ }^{7,9,10}$ It is possible that reservoirs of pathogens could establish themselves at forgotten sites on a ward, posing a continued risk for transmission to patients via unwashed hands. ${ }^{10}$

This study aimed to track potential spread of organisms between surfaces and patients by performing a sequential hand-touch audit. Data gathered would allow us to gain more understanding into transmission pathways of pathogens during patient care as well as help identify items and sites that could benefit from targeted cleaning attention.

\section{Methods}

\section{Monitoring strategy}

One single room was selected on an acute admissions ward in a National Health Service (NHS) hospital. This room afforded excellent views of all patient care without occupants being aware of scrutiny. The ensuite room is regularly used for infected patients and has a wash hand basin inside and alcohol gel fixture outside. Two junior doctors received training for the audit individually and together to exclude observer bias. Each completed $20 \times 30$ min covert sessions, with the first 20 conducted during summer (June-August), and the remainder during winter (February-April). Sessions were performed in the morning (11 sessions during 08:30-12:00); afternoon (18 during 15:00-18:00); and evening (11 during 18:00-20:30) according to clinical responsibilities.

The observer was seated at the nurses' station directly opposite the room entrance. While apparently completing paperwork, the observer monitored all entrants to the room and tracked the sequence of hand-touch events for each entrant therein over a period of $30 \mathrm{~min}$. This was done using a recording strategy containing the following categories: entrant status; hand hygiene on entry (use of alcohol gel and/or wash hand basin); hand contact with near-patient sites (bed frame, bedside locker, curtains, patient console, patient notes); clinical equipment (commode, hoist, blood pressure stand, intravenous drip, stethoscope); direct contact with the patient; hand hygiene on exit (alcohol gel or hand washing); and hand contact with far-patient sites (computer mouse and/or keyboard, filing cabinet, telephone, notes trolley) outside the room (Figure 1). Choice of specific sites was determined by prior observation, whereby fluorescent gel was placed at key sites on multiple occasions with later inspection documenting gel transfer. ${ }^{8,11}$ This allowed us to identify which environmental sites were the most popular recipients for direct handling by staff and helped us construct an appropriate recording strategy. ${ }^{7,8,12}$

Permission for the covert audit was obtained from postgraduate supervisor and senior physicians responsible for the

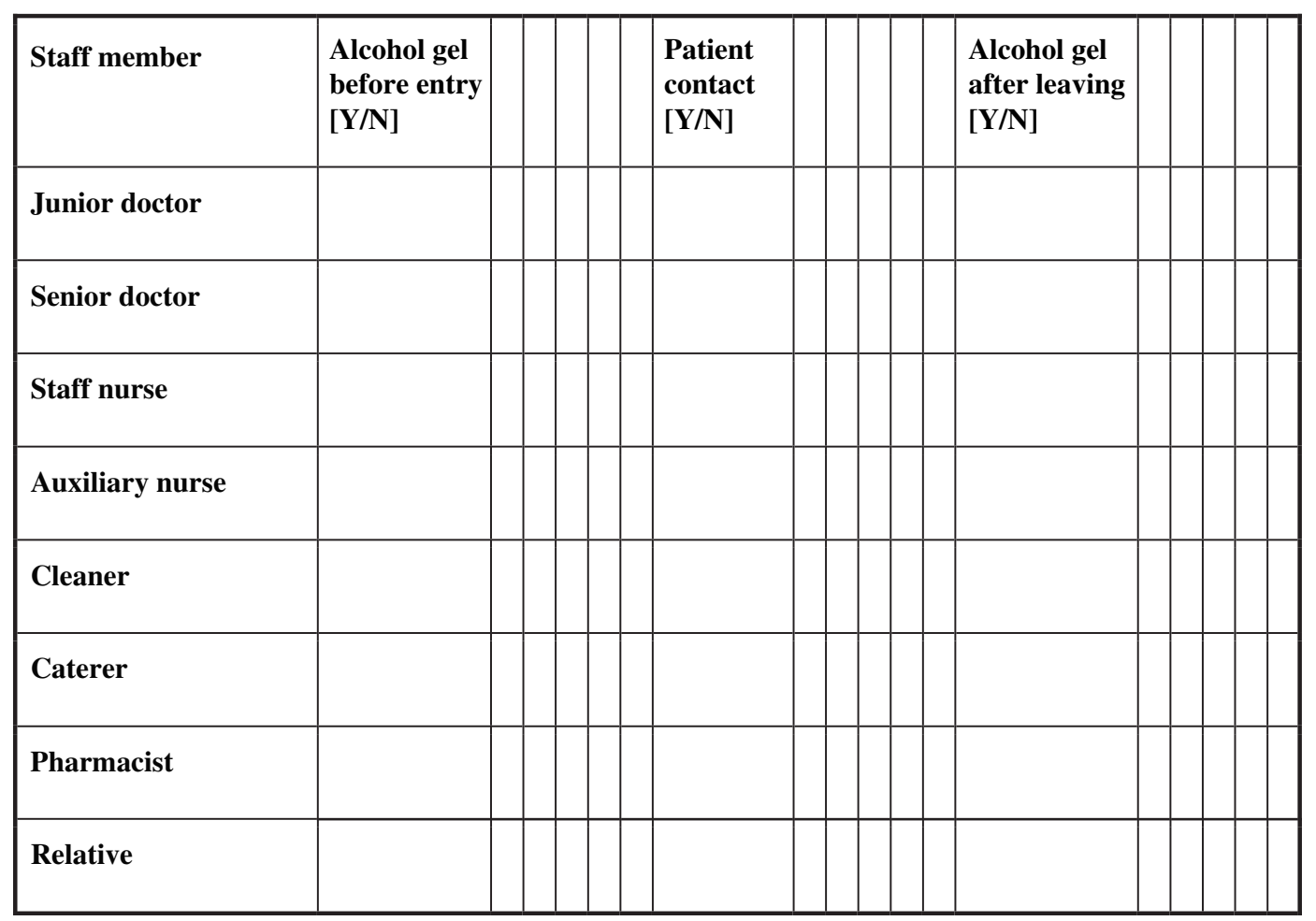

Figure 1. Sequential hand-touch recording strategy. 
ward, without releasing the identity of observers or timing of audit sessions. A 'Zero Tolerance' policy on hand hygiene had been introduced one month before the study began. ${ }^{13}$ Identities of all staff, patients and relatives observed during the study were anonymised, as was the ward and room chosen for the study. Preliminary results were presented at Infection, UK, 2009, and final results to staff at the study hospital and European Congress of Clinical Microbiology and Infectious Diseases, Milan, 2011.

\section{Statistics}

The proportion of contact and cleaning episodes was analysed using logistic regression; 95\% confidence limits (Cls) are used for the percentages and odds ratios (ORs).

\section{Results}

At the time of covert observation, the chosen side room always contained a patient. All had been placed in the room for isolation purposes. These included meticillin-resistant Staphylococcus aureus (MRSA); suspected influenza; diarrhoea; and one patient with suspected neutropaenic sepsis. Overall, 104 people entered the room under observation. They were 59 nurses (38 trained; 21 auxiliary), 18 doctors (three consultants; 15 junior doctors), 21 ancillary staff (15 cleaners; six caterers), one pharmacist and five relatives (Table I). Handhygiene compliance for clinical staff (all nurses and doctors) before entry and after leaving the room was 25\% (doctors: $39 \%$; nurses: $20 \% ; P=0.38$ ). Most hand cleaning occurred before staff entered the room, with very few cleaning their hands on exit. Proportionate differences between hand hygiene on entry and exit were similar whether observed during summer or winter periods. Only one other staff member (a pharmacist) used alcohol gel before entering the room, although four of five relatives used gel before entry. None cleaned hands on exiting, and there was no hand hygiene observed among cleaning or catering staff at any time. These staff did not touch the patient, nor did they handle any clinical equipment. Two of 15 cleaners touched near-patient surfaces, and one used the ward phone directly after exiting. Non-clinical staff and relatives contributed less than $20 \%$ of observations for hand hygiene and surface contacts and are not analysed further.

Nearly two-thirds of clinical staff touched surfaces beside the patient, especially patient notes and bed (Table II). Patient notes were the most frequently handled item throughout the whole study. More than half $(58 \%)$ of clinical staff touched the patient directly as well as clinical equipment (52\%). The most frequently handled item of equipment was the intravenous drip (touched at least once during half of all observed sessions), generally by nurses adjusting the flow rate and/or changing the bag. Outside the room, nearly half $(48 \%)$ of clinical staff touched items at the nurses' station, notably computer, notes trolley and telephone. Most of the doctors handled one or more of these items straight after leaving the room as opposed to a third of nurses.

We compared surface/patient contact and hand hygiene compliance between observation periods performed during the summer and those during the winter (Table II). Hand-hygiene compliance was markedly different for each period. Overall compliance of clinical staff on entry and/or exit in the summer was $47 \%(32 / 68 ; 95 \% \mathrm{Cl}: 35.6-58.8)$ as opposed to $7 \%$ in the winter $(6 / 86 ; 95 \% \mathrm{Cl}: 3.2-14.4)(P<0.0001)$. The $\mathrm{OR}$ for compliance in winter was 0.091 (95\% Cl: $0.032-0.227)$. Of 43 nurses and doctors who entered the room during the winter, only one doctor and one nurse cleaned their hands before entry. There is also evidence that there were fewer patient and surface contact episodes during the winter compared with the summer $(P=0.002)$, with the odds of observing contact activity in winter 0.448 (95\% Cl: $0.269-0.738)$ times that in summer. There is a significant difference between the ORs for winter compared with summer for hand hygiene, compared with patient and environmental contact $(P=0.0043)$. Thus, lower contact with patients in winter compared to summer does not explain lower hand-hygiene levels in winter compared with summer.

Whereas hand hygiene compliance was low, there was an association between hand-hygiene and patient contact, with an OR of 3.44 (95\% Cl: $0.94-16.0 ; P=0.059)$ for touching a patient with clean hands compared with touching a patient without clean hands. This suggests that clinical staff were more likely to clean their hands if there was intent to touch the patient. A similar association was seen between cleaning hands and near-patient sites (OR: 6.76; 95\% Cl: 1.40-65.77; $P=0.0067$ ), although it is impossible to exclude the effect of gaining access to the patient by handling bedside items. There was no association between hand hygiene and touch frequency of clinical equipment (OR: $1.46 ; 95 \% \mathrm{Cl}$ : 0.46-4.75; $P=0.60$ ).

There were three main periods when the audits took place: 11 morning sessions (08:30-12:00); 18 afternoon sessions (15:00-18:00); and 11 evening sessions (18:00-20:30). Data were examined for any differences in practices during each of these three periods. As expected, cleaners entered the room in the morning, caterers delivered food during late afternoon or early evening, and relatives visited in the evenings. Nobody entered the room during one morning session, one evening session and two afternoon sessions. There was an average of more than two (2.5) clinical staff entering per session during the 11 morning sessions (28 entrants in 11 sessions), two (2.0) staff per session during the afternoon periods ( 36 in 18 sessions) and one (1.18) staff member per evening session (13 entrants in 11 sessions). Thus, clinical visits peaked in the morning and diminished thereafter throughout the day. Staff were more likely to handle near-patient hand-touch sites, clinical equipment and touch patients themselves during the observed morning sessions. Far-patient sites outside the room were more likely to be touched during afternoon and evening sessions.

\section{Discussion}

This prospective observational study has illustrated numerous opportunities for pathogens to spread between environmental sites, clinical equipment and patients via hands. We also documented poor compliance with hand hygiene. Staff fail to practice good hand hygiene when they assume auditors are absent since overt audit invariably returns a compliance rate $>90 \%$ in this hospital. ${ }^{2}$ It is possible that both introduction of a 'zero tolerance' policy on hand hygiene one month before the summer sessions and winter workload might explain the differences observed between winter and summer. ${ }^{13-16}$ The zero tolerance policy was well advertised and represented a threat to staff, in that reports of non-compliance could result in a disciplinary procedure. Higher compliance in the summer may have reflected the introduction of this policy. 
Table I

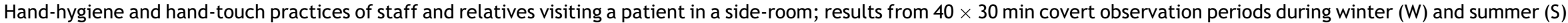
periods

\begin{tabular}{|c|c|c|c|c|c|c|c|c|c|c|c|c|c|c|c|c|c|c|}
\hline \multirow[t]{2}{*}{$\begin{array}{l}\text { Entrant status } \\
\text { (total) }\end{array}$} & \multicolumn{3}{|c|}{$\begin{array}{l}\text { Hand hygiene on } \\
\text { entry }^{a}\end{array}$} & \multicolumn{3}{|c|}{$\begin{array}{l}\text { Contact near-patient } \\
\text { site }\end{array}$} & \multicolumn{3}{|c|}{ Patient contact } & \multicolumn{3}{|c|}{$\begin{array}{c}\text { Contact clinical } \\
\text { equipment }\end{array}$} & \multicolumn{3}{|c|}{$\begin{array}{l}\text { Hand hygiene } \\
\text { on exit }\end{array}$} & \multicolumn{3}{|c|}{ Contact far-patient site } \\
\hline & $\mathrm{S}$ & W & Total & $S$ & W & Total & $S$ & W & Total & $\mathrm{S}$ & W & Total & $\mathrm{S}$ & W & Total & $S$ & W & Total \\
\hline $\begin{array}{l}\text { Junior doctor }(15) \\
\quad(S=10, W=5)\end{array}$ & 5 & 0 & 5 & 8 & 4 & 12 & 6 & 2 & 8 & 2 & 0 & 2 & 4 & 1 & 5 & 10 & 4 & 14 \\
\hline $\begin{array}{l}\text { Senior doctor } \\
\qquad(3)(S=2, W=1)\end{array}$ & 1 & 1 & 2 & 2 & 1 & 3 & 2 & 1 & 3 & 2 & 0 & 2 & 1 & 1 & 2 & 1 & 1 & 2 \\
\hline $\begin{array}{l}\text { All doctors }(18) \\
\qquad(\mathrm{S}=12, \mathrm{~W}=6)\end{array}$ & $\begin{array}{l}6 \\
(50 \%)\end{array}$ & $\begin{array}{l}1 \\
(17 \%)\end{array}$ & $\begin{array}{l}7 \\
(39 \%)\end{array}$ & $\begin{array}{l}10 \\
(83 \%)\end{array}$ & $\begin{array}{l}5 \\
(83 \%)\end{array}$ & $\begin{array}{l}15 \\
(83 \%)\end{array}$ & $\begin{array}{l}8 \\
(67 \%)\end{array}$ & $\begin{array}{l}3 \\
(50 \%)\end{array}$ & $\begin{array}{l}11 \\
(61 \%)\end{array}$ & $\begin{array}{l}4 \\
(33 \%)\end{array}$ & 0 & $\begin{array}{l}4 \\
(22 \%)\end{array}$ & $\begin{array}{l}5 \\
(42 \%)\end{array}$ & $\begin{array}{l}2 \\
(33 \%)\end{array}$ & $\begin{array}{l}7 \\
(39 \%)\end{array}$ & $\begin{array}{l}11 \\
(92 \%)\end{array}$ & $\begin{array}{l}5 \\
(83 \%)\end{array}$ & $16(89 \%)$ \\
\hline $\begin{array}{l}\text { Trained nurse }(38) \\
\qquad(S=16, W=22)\end{array}$ & 9 & 1 & 10 & 11 & 2 & 23 & 10 & 10 & 20 & 8 & 11 & 19 & 6 & 0 & 6 & 10 & 3 & 13 \\
\hline $\begin{array}{l}\text { Auxiliary nurse }(21) \\
\quad(S=6, W=15)\end{array}$ & 2 & 0 & 2 & 3 & 8 & 11 & 5 & 9 & 14 & 6 & 6 & 12 & 4 & 2 & 6 & 2 & 6 & 8 \\
\hline $\begin{array}{l}\text { All nurses (59) } \\
\qquad(S=22, W=37)\end{array}$ & $\begin{array}{l}11 \\
(50 \%)\end{array}$ & $\begin{array}{l}1 \\
(3 \%)\end{array}$ & $\begin{array}{l}12 \\
(20 \%)\end{array}$ & $\begin{array}{l}14 \\
(64 \%)\end{array}$ & $\begin{array}{l}20 \\
(54 \%)\end{array}$ & $\begin{array}{l}34 \\
(58 \%)\end{array}$ & $\begin{array}{l}15 \\
(68 \%)\end{array}$ & $\begin{array}{l}19 \\
(51 \%)\end{array}$ & $\begin{array}{l}34 \\
(58 \%)\end{array}$ & $\begin{array}{l}14 \\
(64 \%)\end{array}$ & $\begin{array}{l}17 \\
(46 \%)\end{array}$ & $\begin{array}{l}31 \\
(52 \%)\end{array}$ & $\begin{array}{l}10 \\
(45 \%)\end{array}$ & $\begin{array}{l}2 \\
(5 \%)\end{array}$ & $\begin{array}{l}12 \\
(20 \%)\end{array}$ & $\begin{array}{l}12 \\
(54 \%)\end{array}$ & $\begin{array}{l}9 \\
(24 \%)\end{array}$ & $21(36 \%)$ \\
\hline $\begin{array}{l}\text { All clinical staff }{ }^{\mathrm{b}}(77) \\
(\mathrm{S}=34, \mathrm{~W}=43)\end{array}$ & $\begin{array}{l}17 \\
(50 \%)\end{array}$ & $\begin{array}{l}2 \\
(5 \%)\end{array}$ & $\begin{array}{l}19 \\
(25 \%)\end{array}$ & $\begin{array}{l}24 \\
(71 \%)\end{array}$ & $\begin{array}{l}25 \\
(58 \%)\end{array}$ & $\begin{array}{l}49 \\
(64 \%)\end{array}$ & $\begin{array}{l}23 \\
(68 \%)\end{array}$ & $\begin{array}{l}22 \\
(51 \%)\end{array}$ & $\begin{array}{l}45 \\
(58 \%)\end{array}$ & $\begin{array}{l}18 \\
(53 \%)\end{array}$ & $\begin{array}{l}17 \\
(39 \%)\end{array}$ & $\begin{array}{l}35 \\
(45 \%)\end{array}$ & $\begin{array}{l}15 \\
(44 \%)\end{array}$ & $\begin{array}{l}4 \\
(9 \%)\end{array}$ & $\begin{array}{l}19 \\
(25 \%)\end{array}$ & $\begin{array}{l}23 \\
(68 \%)\end{array}$ & $\begin{array}{l}14 \\
(33 \%)\end{array}$ & $\begin{array}{l}37 \\
(48 \%)\end{array}$ \\
\hline $\begin{array}{l}\text { Cleaner }(15) \\
\quad(S=0, W=15)\end{array}$ & 0 & 0 & 0 & 0 & 2 & 2 & 0 & 0 & 0 & 0 & 0 & 0 & 0 & 0 & 0 & 0 & 1 & 1 \\
\hline $\begin{array}{l}\text { Caterer }(6) \\
\quad(S=6, W=0)\end{array}$ & 0 & 0 & 0 & 0 & 0 & 0 & 0 & 0 & 0 & 0 & 0 & 0 & 0 & 0 & 0 & 0 & 0 & 0 \\
\hline $\begin{array}{l}\text { Pharmacist }(1) \\
\qquad(\mathrm{S}=1, \mathrm{~W}=0)\end{array}$ & 1 & 0 & 1 & 1 & 0 & 1 & 0 & 0 & 0 & 0 & 0 & 0 & 0 & 0 & 0 & 1 & 0 & 1 \\
\hline $\begin{array}{l}\text { All other staff }(22) \\
\qquad(S=7, W=15)\end{array}$ & 1 & 0 & $1(4 \%)$ & 1 & 2 & $3(14 \%)$ & 0 & 0 & 0 & 0 & 0 & 0 & 0 & 0 & 0 & 1 & 1 & 2 (10\%) \\
\hline $\begin{array}{l}\text { Relatives }(5) \\
\qquad(S=0, W=5)\end{array}$ & 0 & 4 & $4(80 \%)$ & 0 & 3 & $3(60 \%)$ & 0 & 1 & 1 (20\%) & 0 & 0 & 0 & 0 & 0 & 0 & 0 & 0 & 0 \\
\hline
\end{tabular}

${ }^{a}$ Staff who cleaned their hands on entry to the room were not necessarily the same individuals who cleaned their hands on exiting the room.

b Clinical staff includes all doctors and nurses. 
Table II

Number of near-patient sites, clinical equipment and far-patient sites touched by 104 side-room entrants during $40 \times 30$ min covert observation periods

\begin{tabular}{|c|c|c|c|}
\hline $\begin{array}{l}\text { Category of surface touched or handled } \\
\text { during } 40 \times 30 \text { min observed sessions }\end{array}$ & Site & Total no. of times touched & $\begin{array}{l}\% \text { touched of all } \\
\text { sites handled }\end{array}$ \\
\hline \multirow[t]{6}{*}{ Near-patient surfaces (in room) } & Patient console & 8 & $5 \%$ \\
\hline & Notes & 37 & $22 \%$ \\
\hline & Bed frame & 19 & $11 \%$ \\
\hline & Locker & 4 & $2 \%$ \\
\hline & Curtains & 6 & $4 \%$ \\
\hline & Category total (\%) & 74 & $44 \%$ \\
\hline \multirow[t]{6}{*}{ Clinical equipment (in room) } & Hoist & 0 & $0 \%$ \\
\hline & Commode & 4 & $2 \%$ \\
\hline & BP stand & 10 & $6 \%$ \\
\hline & Stethoscope & 3 & $2 \%$ \\
\hline & IV drip & 23 & $14 \%$ \\
\hline & Category total (\%) & 40 & $24 \%$ \\
\hline \multirow[t]{5}{*}{ Far-patient surfaces (outside room) } & Computer & 20 & $12 \%$ \\
\hline & Filing cabinet & 0 & 0 \\
\hline & Notes trolley & 18 & $11 \%$ \\
\hline & Telephone & 16 & $9 \%$ \\
\hline & Category total (\%) & 54 & $32 \%$ \\
\hline Total items touched & & 168 & $100 \%$ \\
\hline
\end{tabular}

$\mathrm{BP}$, blood pressure; IV, intravenous.

Total number of times handled exceeds values listed in Table I since some items were touched on multiple occasions.

Poor compliance noted in winter might have been due to workload, particularly since 'zero tolerance' was not advertised before or during the winter sessions. ${ }^{16}$ Bed occupancy rates for the medical unit during the summer were 93-95\%, whereas those for the winter were $>97 \%$. These rates are calculated according to occupancy in a bed at midnight. In winter, the admissions ward is so busy that patients are admitted and then transferred to other wards during the day, so that the occupancy rates recorded do not necessarily reflect patient turnover on the ward. In addition, staff themselves are more likely to take sick leave during the winter, leaving busy wards short-staffed.

Morning, afternoon and evening sessions were unequally divided between summer and winter periods, in that nine of 11 morning sessions took place during the winter period. Given poor hand-hygiene compliance during the winter, we cannot draw any conclusions regarding disparity in compliance at different times during the day. It is possible that work pressures in the mornings led to reduced hand hygiene and this would have confounded the overall compliance rate seen during the winter. Hand-hygiene compliance has been correlated with workload. ${ }^{17}$ Another study reported that lower levels of compliance were found for HCWs working during the early shift. ${ }^{18}$ Compliance was universally poor throughout all winter sessions, whether observation occurred during morning, afternoon or evening.

Staff were more likely to touch patients, near-patient sites and equipment in the morning whereas sites outside the room were more likely to be touched during afternoon and evening sessions. If cleaning schedules take account of this, then staff should clean patient rooms early in the day. How much they should do later on requires strategic planning, since many highrisk sites are not usually cleaned by domestic staff. Clinical equipment, usually a nursing responsibility, should be cleaned immediately after use. Computers, telephones and trolleys should also be cleaned daily. Given the frequency with which they are touched every day, keeping them continually microbiologically clean would be challenging. ${ }^{19}$

Even exemplary hygiene practices are rendered invalid if the first site touched transfers pathogens to fingertips. Patients occupying rooms previously occupied by patients colonized or infected with various hospital pathogens have a $54 \%$ increased risk of acquiring the same pathogen than patients not occupying such rooms. ${ }^{20}$ These findings can only be explained by suboptimal cleaning since they illustrate the role of the hospital environment in pathogen transmission regardless of hand hygiene. A brief environmental screen of the room under observation was performed, demonstrating high aerobic colony counts at six of ten sites on near-patient surfaces and clinical equipment, with $S$. aureus isolated from bedside locker and both S. aureus and MRSA found on the overbed table. Further support for the role of the environment comes from a study examining MRSA carriage on nurses' hands in a hospital. ${ }^{21}$ MRSA was found more often from hands after contact with the environment than following patient contact. ${ }^{21}$

Beds, lockers and overbed tables have been highlighted in previous studies examining hand-touch frequency of surfaces and pathogen reservoirs. $6,12,22,23$ The proximity of these sites to patients raises the possibility that it could be patients' own hands that transfer microbes. ${ }^{24,25}$ This illustrates a major limitation of this study, in that we did not include hand-touch practices of patients themselves. This was due to the fact that although observers were confident of tracking the movement of staff hands, they could not always see all of the patients' hand movements. Indeed, the hands of relatives and other visitors may all play a part in pathogen transmission. ${ }^{24,25}$ Clean hands are important for everyone, regardless of status, and a bedbound patient will not necessarily remember, or be helped, to practice hand hygiene. 
Although we attempted to eradicate observer bias as far as possible, there may have been differences in recording exact progression of hand-touch events. The first observer trained the second and the recording strategy was piloted and standardized before each period began. It is possible that some errors may have occurred during particularly busy sessions, because the observer may not have been able to simultaneously record multiple entries. Even if this did occur, any errors made would not have changed the overall findings. Neither observer was 'discovered' by colleagues during covert sessions.

The sequence of hand-touch practices by staff during clinical activities provides a theoretical demonstration of how hospital organisms could spread from one environmental site to another. Cleaning specifications can target these high-risk sites but even this cannot remove all risk. Everyone in the healthcare environment - staff, patients and relatives - must keep their hands clean. The 'hand = hand-touch site' equation is equal and opposite and both hand hygiene and cleaning are required in order to reduce the risk of infection as far as possible. The effectiveness of such a strategy regarding vancomycin-resistant enterococcus transmission has already been demonstrated. ${ }^{26}$ Clearly, hospitals would benefit from targeted cleaning as well as continued emphasis on hand hygiene practices. ${ }^{25}$

\section{Acknowledgements}

We would like to acknowledge study hospital consultants and local infection control staff for supporting the audit.

\section{Conflict of interest statement}

None declared.

\section{Funding sources}

None.

\section{References}

1. Kampf G, Kramer A. Epidemiologic background of hand hygiene and evaluation of the most important agents for scrubs and rubs. Clin Microbiol Rev 2004;17:863-893.

2. Gould D, Hewitt-Taylor J, Drey NS, Gammon J, Chudleigh J, Weinberg JR. The CleanYourHandsCampaign: critiquing policy and evidence base. J Hosp Infect 2007;65:95-101.

3. Dancer SJ. The role of environmental cleaning in the control of hospital-acquired infection. J Hosp Infect 2009;73:378-385.

4. Farr B, Salgado CD, Karchmer TB, Sherertz RJ. Can antibioticresistant infections be controlled? Lancet Infect Dis 2001;1:38-45.

5. Bhalla A, Pultz NJ, Gries DM, et al. Acquisition of nosocomial pathogens on hands after contact with environmental surfaces near hospitalised patients. Infect Control Hosp Epidemiol 2004;25:164-167.

6. Dancer SJ, White LF, Lamb J, Girvan EK, Robertson C. Measuring the effect of enhanced cleaning in a UK hospital: a prospective cross-over study. BMC Med 2009;7:28.

7. Anderson RE, Young V, Stewart M, Robertson C, Dancer SJ. Cleanliness audit of clinical surfaces and equipment: who cleans what? J Hosp Infect 2011;78:178-181.
8. Carling PC, Briggs J, Hylander D, Perkins J. An evaluation of patient area cleaning in 3 hospitals using a novel targeting methodology. Am J Infect Control 2006;34:513-519.

9. White L, Dancer SJ, Robertson C, McDonald J. Are hygiene standards useful in assessing infection risk? Am J Infect Control 2008; 36:381-384.

10. Lloyd-Hughes R, Talbot S, Jumaa P. Bedside Bibles, notes trolleys and other forgotten sites for cleaning. J Hosp Infect 2008;69:200-201.

11. Oelberg DG, Joyner SE, Jiang X, Laborde D, Islam MP, Pickering LK. Detection of pathogen transmission in neonatal nurseries using DNA markers as surrogate indicators. Pediatrics 2000;105: 311-315.

12. Goodman ER, Platt R, Bass R, Onderdonk AB, Yokoe DS, Huang SS. Impact of an environmental cleaning intervention on the presence of methicillin-resistant Staphylococcus aureus and vancomycinresistant enterococci on surfaces in intensive care unit rooms. Infect Control Hosp Epidemiol 2008;29:593-599.

13. Dancer SJ. Pants, policies and paranoia. J Hosp Infect 2010;74: 10-15.

14. Goldmann D. System failure versus personal accountability - the case for clean hands. New Engl J Med 2006;355:121-123.

15. Gould DJ, Drey NS, Creedon S. Routine hand hygiene audit by direct observation: has nemesis arrived? J Hosp Infect 2011;77: 290-293.

16. Eckmanns T, Rath A, Ruden H, Gastmeier P, Daschner F. Outbreak of Enterobacter cloacae related to understaffing, overcrowding, and poor hygiene practices. Infect Control Hosp Epidemiol 2000;21:305-307.

17. Scheithauer S, Haefner H, Schwanz T, et al. Compliance with hand hygiene on surgical, medical, and neurologic intensive care units: direct observation versus calculated disinfectant usage. Am J Infect Control 2009;37:835-841.

18. Randle J, Arthur A, Vaughan N. Twenty-hour observational study of hospital hand hygiene compliance. J Hosp Infect 2010;76: 252-255.

19. Aldeyab MA, McElnay J, Elshibly SM, et al. Evaluation of the efficacy of a conventional cleaning regimen in removing methicillin-resistant Staphylococcus aureus from contaminated surfaces in an intensive care unit. Infect Control Hosp Epidemiol 2009;30:304-306.

20. Carling PC, Bartley JM. Evaluating hygienic cleaning in healthcare settings: what you do not know can harm your patients. Am J Infect Control 2010;38:S41-S50.

21. Creamer E, Dorrian S, Dolan A, et al. When are the hands of healthcare workers positive for meticillin-resistant Staphylococcus aureus? J Hosp Infect 2010;75:107-111.

22. Dancer SJ, White L, Robertson C. Monitoring environmental cleanliness on two surgical wards. Int J Environ Hygiene 2008; 18:357-364.

23. Huslage K, Rutala WA, Sickbert-Bennett E, Weber DJ. A quantitative approach to defining "High-Touch" surfaces in hospitals. Infect Control Hosp Epidemiol 2010;31:850-853.

24. Gagne D, Bedard G, Maziade PJ. Systematic hand disinfection by patients: impact on meticillin-resistant Staphylococcus aureus infection rates in a community hospital. J Hosp Infect 2010;75: 269-272.

25. Dancer SJ. Control of transmission of infection in hospitals requires more than clean hands. Infect Control Hosp Epidemiol 2010;31:958-960.

26. Hayden MK, Bonten MJM, Blom DW, et al. Reduction in acquisition of vancomycin-resistant enterococcus after enforcement of routine environmental cleaning measures. Clin Infect Dis 2006;42:1552-1560. 